\title{
UJI KETAHANAN FATIK ALUMINIUM SCRAP HASIL REMELTING PISTON BEKAS MENGGUNAKAN ALAT UJI FATIK TIPE ROTARY BENDING
}

\author{
Eko Budiyanto1, Eko Nugroho², Agus Zainudin³ \\ Jurusan Teknik Mesin, Universitas Muhammadiyah Metro \\ Jl. Ki Hajar Dewantara No. 116 Metro, Lampung, Indonesia \\ Email: eko_budiyanto99@yahoo.com ${ }^{1}$, exonugros@gmail.com², aguszainudin@yahoo.com³
}

\begin{abstract}
Abstrak
Aluminium merupakan salah satu logam non-ferrous yang paling banyak dipergunakan dalam bidang keteknikan karena memiliki sifat yang ringan, tahan terhadap korosi, dan dapat didaur ulang. Daur ulang adalah proses untuk menjadikan suatu bahan bekas menjadikan suatu bahan bekas menjadi suatu yang berguna. Dalam penelitian ini dilakukan daur ulang dengan metode remelting aluminium piston bekas dengan harapan nantinya bahan piston bekas dapat dipergunakan kembali. Tujuan penelitian ini adalah untuk mengetahai nilai kelelahan fatik aluminium hasil remelting piston bekas pada variasi beban yang berbeda. Metode penelitian memvariasikan beban 40\%, 50\%, dan 60\% dari Yield Strength untuk menghasilkan nilai kelelahan. Nilai uji fatik dari pembebanan $40 \%$ Yield Strength diberi beban $1,2 \mathrm{~kg}$ mendapatkan nilai siklus putaran 171.026 dan waktu patah 01:34:01 detik. Pada pembebanan 50\% Yield Strength diberi beban 1,5 kg mendapatkan nilai siklus putaran 56.796 dengan waktu patah 00:37:52 detik. Pada pembebanan 60\% Yield Strength diberi beban $1,8 \mathrm{~kg}$ mendapatkan nilai siklus putaran 24.384 dan waktu patah 00:16:15 detik. Semakin besar beban yang diberikan semakin kecil siklus dan waktu yang dihasilkan, sebaliknya semakin kecil beban yang diberikan semakin besar siklus dan waktu yang dihasilkan.
\end{abstract}

Kata kunci : Aluminium scrap, Piston bekas, Remelting, Uji fatik, Rotary bending.

\section{PENDAHULUAN}

Aluminium merupakan salah satu logam non-ferrous yang paling banyak digunakan dalam bidang keteknikan karena memiliki sifat yang ringan dan tahan terhadap korosi, Biasanya paduan aluminium dipadukan dengan unsur-unsur antara lain: $\mathrm{Cu}, \mathrm{Si}, \mathrm{Mg}, \mathrm{Zn}, \mathrm{Mn}, \mathrm{Ni}$ dan masih banyak unsur paduan lainnya. Aluminium mempunyai titik leleh $660^{\circ} \mathrm{C}$ dan masa jenis $2,75 \mathrm{~kg} / \mathrm{m}^{3}$. Sebanding dengan penggunaannya yang bermacammacam maka limbah aluminium banyak ditemukan dan bernilai ekonomis yang lebih rendah dari pada bahan lain [1]. Namun hal ini dapat diatasi dengan cara didaur ulang.

Daur ulang adalah proses untuk menjadikan suatu barang bekas menjadi bahan baru dengan tujuan mencegah adanya sampah sebenarnya dapat menjadi sesuatu yang berguna, mengurangi populasi, kerusakan lahan, dan emisi gas rumah kaca jika dibandingkan dengan proses pembuatan barang baru. Bahan aluminium yang sudah tidak bisa digunakan seperti salah satu komponen mesin (piston bekas) masih bisa dimanfaatkan lagi dengan cara didaur ulang (remelting).

Dari proses daur ulang piston bekas ini, sifat material aluminium yang didaur ulang tentu tidak sama dengan material aluminium yang sebelum didaur ulang, terutama sifat mekanisnya. Salah satu sifat mekanis material yang sulit untuk diperkirakan kapan terjadinya dan tidak dapat dilihat secara kasat mata adalah sifat ketahanan material terhadap kegagalan 
fatik. Kegagalan fatik ada 3 fasa yaitu: awal retak (initiation), perambatan retak (crack propogation), dan perpatahan akhir (fracture frailure). Lebih dari $90 \%$ penyebab kegagalan mekanik adalah disebabkan oleh kelelahan (fatik) [2]. Untuk itu perlu dilakukan uji ketahanan fatik material Aluminium hasil daur ulang limbah otomotif dalam hal ini adalah piston bekas.

Dalam penelitian ini, diharapkan nantinya material Aluminium yang sudah tidak dapat digunakan seperti piston bekas, dapat dimanfaatkan kembali sebagai bahan baku pembuatan velg, pully, dan lain-lain, sesuai dengan kebutuhan konsumen dari pemanfaatan limbah piston tersebut.

\section{TINJAUAN PUSTAKA}

\section{Aluminium}

Aluminium adalah logam berwarna

putih keperakan yang lunak dan merupakan logam yang paling banyak terdapat di kerak bumi, dan unsur ketiga terbanyak setelah oksigen dan silikon. Aluminium terdapat dikerak bumi sebanyak kira-kira $8,07 \%$ hingga $8,23 \%$ dari seluruh massa padat dari kerak bumi,dengan produksi tahunan dunia sekitar 30 juta ton pertahun dalam bentuk bebatuan.

Aluminium ditemukan oleh Sir Humprey Davy 1809 sebagai suatu unsur, dan pertama kali direduksi sebagai logam oleh H. C. Oersted, 1825. Secara industri Paul Heroult di perancis dan C. M. Hall di amerika serikat secara terpisah telah memperoleh logam aluminium dari alumina dengan cara elektrolisa dari garamnya yang terfusi. Sampai sekarang peroses Heroult Hall masih masih dipakai untuk memproduksi aluminium.

Aluminium merupakan salah satu logam non-ferrous yang paling banyak dipergunakan dalam bidang keteknikan karena memiliki sifat yang ringan dan tahan terhadap korosi. Terdapat banyak paduan dari aluminium diantaranya seperti $\mathrm{Al}-\mathrm{Si}, \mathrm{Al}-\mathrm{Cu}, \mathrm{Al}-\mathrm{Mg}$ dn Al-Zn serta banyak paduan-paduan aluminium lainnya.
Masing-masing paduan ini mempunyai karaktaristik yang berbeda-beda dengan tujuan pemakaian yang berbeda pula. Aluminium dipergunakan secara luas bukan saja untuk peralatan rumah tangga, tetapi juga dipakai untuk keperluan matrial pesawat terbang, otomotif, kapal laut, konstruksi dan lain-lain [1].

Tabel 1. Sifat fisik aluminium

\begin{tabular}{|l|l|l|}
\hline \multirow{2}{*}{\multicolumn{1}{|c|}{ Sifat-sifat }} & \multicolumn{2}{c|}{ Kemurnian $\mathrm{Al}$} \\
\cline { 2 - 3 } & $99,996 \%$ & $>99,0 \%$ \\
\hline Massa jenis $\left(20^{\circ} \mathrm{C}\right)$ & 2,6989 & 2,71 \\
\hline Titik cair & 660,2 & $653-657$ \\
\hline Panas jenis & 0,2226 & 0,2297 \\
\hline$\left(\mathrm{cal} / \mathrm{g} .{ }^{\circ} \mathrm{C}\right)\left(100^{\circ} \mathrm{C}\right)$ & & $\begin{array}{l}59 \\
(\text { dianil })\end{array}$ \\
\hline $\begin{array}{l}\text { Hantaran listrik } \\
(\%)\end{array}$ & 64,94 & $\begin{array}{l}23,5 \times \\
10^{-6}\end{array}$ \\
\hline $\begin{array}{l}\text { Koefisien } \\
\text { pemuaian }(20- \\
\left.100^{\circ} \mathrm{C}\right)\end{array}$ & $\begin{array}{l}23,86 \times \\
10^{-6}\end{array}$ & \\
\hline
\end{tabular}

Tabel 2. sifat mekanik aluminium [1]

\begin{tabular}{|c|c|c|c|c|}
\hline \multirow{2}{*}{$\begin{array}{c}\text { Sifat }- \\
\text { sifat }\end{array}$} & \multicolumn{4}{|c|}{ Kemurnian Al (\%) } \\
\cline { 2 - 5 } & Dianil & $\begin{array}{c}74 \% \text { dirol } \\
\text { dingin }\end{array}$ & Dianil & $\mathrm{H} 18$ \\
\hline $\begin{array}{c}\text { Kekuatan } \\
\text { Tarik } \\
\left(\mathrm{kg} / \mathrm{mm}^{2}\right)\end{array}$ & 4,9 & 11,6 & 9,3 & 16,9 \\
\hline $\begin{array}{c}\text { Kekuatan } \\
\text { Mulur } \\
(0,2 \%)(\mathrm{kg} / \\
\text { mm²) }\end{array}$ & 1,3 & 11,0 & 3,5 & 14,8 \\
\hline $\begin{array}{c}\text { Perpanjan } \\
\text { g (\%) }\end{array}$ & 4,8 & 5,5 & 35 & 5 \\
\hline $\begin{array}{c}\text { Kekerasan } \\
\text { Brinell }\end{array}$ & 17 & 27 & 23 & 44 \\
\hline
\end{tabular}

Piston merupakan paduan aluminium dengan silikon (Al-Si). Piston yang dalam bahasa Indonesia dikenal dengan istilah torak adalah komponen penting dalam kendaraan bermotor, karena piston memegang peranan penting dalam proses pembakaran dalam ruang bakar. Sehingga material untuk piston merupakan material dengan spesifikasi khusus dan biasanya digunakan bijih aluminium untuk membuat paduannya. Komponen mesin ini dipegang oleh stang piston yang 
mendapatkan gerakan naik turun dari gerakan berputar cranksaft.

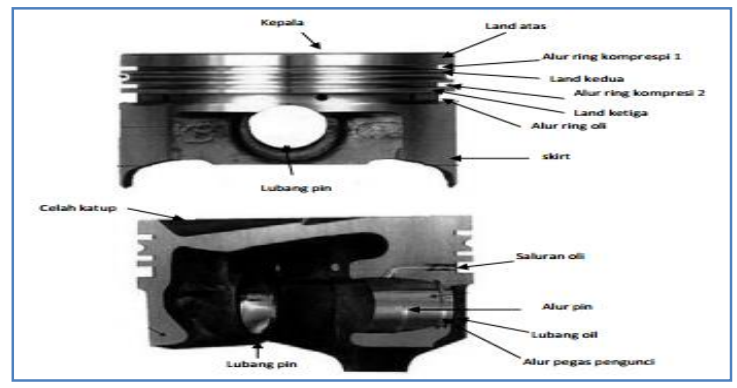

Gambar 1. Piston

Piston yang mengalami kerusakan pada akhirnya tidak dapat bekerja sesuai dengan fungsinya sehingga akan menjadi limbah. Untuk mengurangi penumpukan limbah aluminium piston, maka limbah aluminium piston bekas tersebut dapat dimanfaatkan dengan cara mendaur ulang (remelting) [3].

\section{Remelting}

Remelting merupakan salah satu metode pengecoran daur ulang dengan melebur kembali material logam yang telah ada. Keuntungan dari remelting ini diantaranya harganya yang relatif murah dan dapat dilakukan oleh industri meskipun hanya skala rumah tangga (home industry). Peleburan aluminium paduan dengan metode remelting dapat dilakukan dalam dapur kowi karena aluminium mempunyai titik lebur yang tidak terlalu tinggi. Untuk menghemat waktu peleburan dan mengurangi kehilangan karena oksidasi, maka perlu dilakukan pemotongan logam menjadi potongan kecil yang diberi panas mula [4].

Suhu penuangan dalam proses pengecoran merupakan salah satu hal yang sangat berpengaruh penting, karena akan sangat berpengaruh dalam hasil cetakan. Suhu tuang aluminium yang terlalu rendah maka rongga cetakan tidak akan terisi penuh dimana saluran masuk akan terbuka terlebih dahulu, dan apabila suhu tuang terlalu tinggi maka hal ini akan mengakibatkan penyusutan dan kehilangan akan keakuratan dimensi coran. Suhu tuang pada aluminium biasanya terdapat pada range $675-790^{\circ} \mathrm{c}$ dan harus tetap diperhatikan pada saat penuangan [5].

\section{Uji Fatik}

Fatigue atau kelelahan adalah kerusakan material yang diakibatkan oleh adanya tegangan yang berfluktuasi yang besarnya lebih kecil dari Yield Strength material yang diberikan beban konstan. Terdapat tiga fase dalam perpatahan fatik yaitu :

1. Permulaan retak Mekanisme fatik umumnya dimulai dari crack initiation yang terjadi di permukaan material yang lemah atau daerah dimana terjadi konsentrasi tegangan di permukaan (seperti goresan, notch, lubang-pits dll) akibat adanya pembebanan berulang.

2. Penyebaran retak Crack initiation ini berkembang menjadi microcracks. Perambatan atau perpaduan microcracks ini kemudian membentuk macrocracks yang akan berujung pada failure.

3. Perpatahan Akhir Perpatahan terjadi ketika material telah mengalami siklus tegangan dan regangan yang menghasilkan kerusakan yang permanen.

Salah satu jenis kegagalan yang terjadi pada komponene yang diakibatkan beban dinamis (pembebanan yang berulang-ulang dan berbeda-beda) dapat menyebabkan suatu material mengalami patah (fracture). Kegagalan komponen atau struktur dapat dibedakan menjadi dua katagori utama yaitu : pertama kegagalan quasi statik (kegagalan yang tidak tergantung pada waktu, dan ketahanannya dinyatakan dengan kekuatan). Kedua kegagalan yang tergantung pada waktu ketahanan terhadap kegagalannya dinyatakan dengan umur [6].

Penyajian data fatik adalah menggunakan kurva S-N yaitu pemetaan tegangan (S) terhadap jumlah siklus sampai terjadi kegagalan (N). Kurva S-N ini lebih diutamakan menggunakan skala semi log seperti ditunjukan pada gambar 2 . Untuk beberapa bahan teknis yang penting, 
kurva tersebut didapat dari pemetaan tegangan terhadp jumlah siklus sampai terjadi kegagalan pada benda uji. Pada kurva ini siklus menggunakan sekala logaritma. Batas ketahan fatik (endurance limit) aluminium ditentukan pada jumlah siklus $\mathrm{N}>10^{7}$.

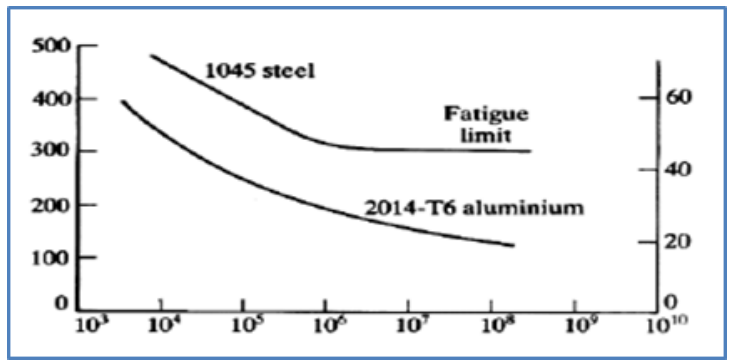

Gambar 2. Kurva S-N

Untuk mencari siklus digunakan perkalian antara waktu dengan putaran motor.

$$
\mathrm{N}=t \times n
$$

Keterangan:

$$
\begin{aligned}
& \mathrm{N}=\text { Siklus } \\
& t=\text { waktu ( menit ) } \\
& n=\text { putaran motor ( Rpm ) [2]. }
\end{aligned}
$$

Pengujian fatigue dilakukan dengan cara memberikan stress level tertentu sehingga spesimen patah pada siklus tertentu. Retak fatigue biasanya dimulai pada permukaan di mana lentur dan torsi menyebabkan terjadinya tegangan-tegangan yang tinggi atau di tempat-tempat yang tidak rata menyebabkan terjadinya konsentrasi tegangan. Oleh karena itu, batas ketahanan (endurance limit) sangat tergantung pada kualitas permukaan.

Pengujian fatigue dilakukan dengan Rotary Bending Machine. Jika benda uji diputar dan diberi beban, maka akan terjadi momen lentur pada benda uji. Momen lentur ini menyebabkan terjadinya beban lentur pada benda uji. Momen lentur ini menyebabkan terjadinya beban lentur pada permukaan benda uji dan besarnya dihitung dengan persamaan [2].

$$
\sigma=\frac{w \cdot L / 2}{\pi / 32 \cdot d^{3}} \mathrm{~kg} / \mathrm{cm}^{2}
$$

Dengan

$$
\begin{aligned}
& \sigma=\text { Tegangan lentur }\left(\mathrm{kg} / \mathrm{cm}^{2}\right) \\
& w=\text { Beban lentur }(\mathrm{kg}) \\
& d=\text { Diameter benda uji }(\mathrm{cm})
\end{aligned}
$$

\section{METODE PENELITIAN}

\section{Metode Pengujian}

Sebelum melakukan uji fatik, material terlebih dahulu diuji tarik untuk mendapatkan nilai yield strength. Setelah diketahui nilai yield strength-nya, maka ditentukan nilai pembebanan untuk uji fatik yakni $40 \%$, 50\%, dan $60 \%$ dari nilai yield strength.

\section{Spesimen}

Spesimen yang akan digunakan ASTM E8 untuk uji fatik dan tarik, dari hasil pengecoran aluminium piston bekas.

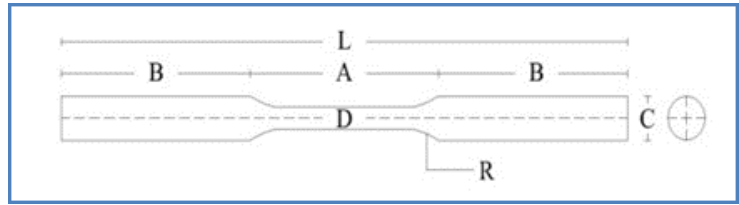
Ket : $\quad$ D : $6 \mathrm{~mm}$
L : $180 \mathrm{~mm}$
$\mathrm{C}: 12 \mathrm{~mm}$
A : $60 \mathrm{~mm}$
B : $60 \mathrm{~mm}$
$\mathrm{R}: 6$

Gambar 2. Spesimen uji tarik [7].

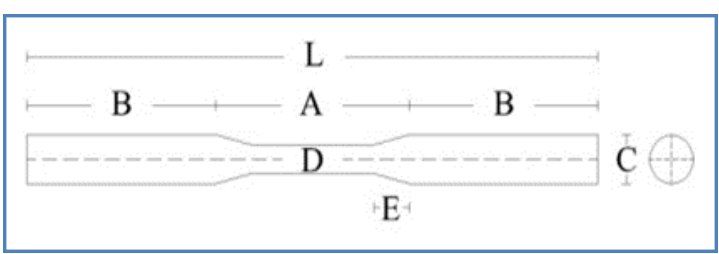
Ket : $\quad$ D : $6 \mathrm{~mm}$
$\mathrm{L}: 130 \mathrm{~mm}$
$\mathrm{C}: 10 \mathrm{~mm}$
A : $44 \mathrm{~mm}$
B : $43 \mathrm{~mm}$
E : $8 \mathrm{~mm}$

Gambar 3. Spesimen uji fatik [7].

Tabel 3. Hasil Pengujian Tarik

\begin{tabular}{|c|c|c|c|}
\hline $\begin{array}{c}\text { Spesime } \\
\mathrm{n}\end{array}$ & $\begin{array}{c}\text { Utimat } \\
\text { e Stress }\end{array}$ & $\begin{array}{c}\text { Yield } \\
\text { Strengt } \\
h\end{array}$ & $\begin{array}{c}\text { Elasticit } \\
y \\
\text { Modulus }\end{array}$ \\
\hline $700^{\circ} \mathrm{C}$ & 124,71 & $\begin{array}{c}124,716 \\
\mathrm{MPa}\end{array}$ & $\begin{array}{c}62.193 \\
\mathrm{Mpa}\end{array}$ \\
\hline
\end{tabular}




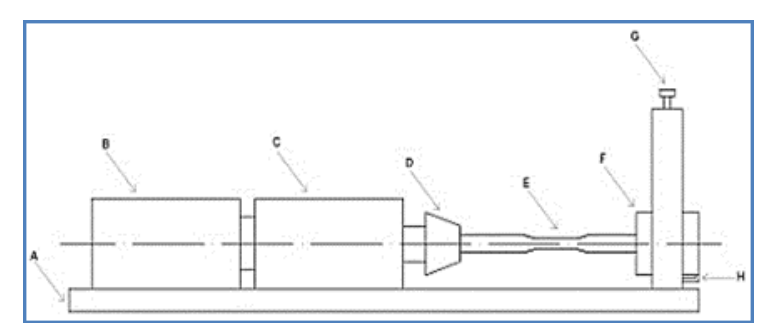

A. Alas penyangga

B. Motor listrik

C. Box senson siklus

D. Pencekam

E. Benda uji

F. Pencekam bearing

G. Pengatur beban

H. .Sensor patahan bending

Gambar 4. Skema Mesin Uji Fatik Tipe Rotary Bending

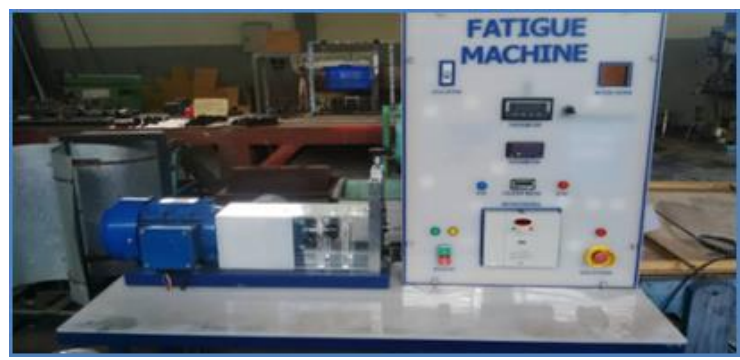

Gambar 5. Mesin Uji Fatik Tipe Rotary Bending

\section{Langkah peleburan Aluminium}

1. Menyiapkan alat dan bahan untuk peleburan aluminium,

2. Memasasukkan bahan bakar (cangkang karet) pada ruang bakar setinggi penyangga dan memulai proses pembakaran,

3. Memasukkan alumunium piston bekas,

4. Menutup dapur krusibel,

5. Setelah aluminium mencair dipertahankan hingga temperatur $700^{\circ} \mathrm{C}$,

6. Melakukan penuangan Aluminium yang sudah mencair cetakan yang sudah disiapkan.

7. Setelah selesai peleburan, api dipadamkan dan dilakukan pembersihan tungku dan lingkungan sekitar proses peleburan.bara api.

\section{Langkah pengujian}

Sebelum melakukan pengambilan data pengujian ftik, sudah terlebih dahulu dilakukan uji tarik untuk mengetahui nilai
Yield Strength. Langkah-langkah pengujian fatik adalah sebagai berikut:

1. Setelah diketahui nilai Yield Strength dari pengujian tarik, maka ditentukan berat pembeban yaitu $40 \%, 50 \%$, dan $60 \%$ dari nilai Yield Strength,

2. Memasang spesimen pada pencekam dan dieratkan dengan kuat,

3. Memasang cover transparan,

4. Menghubungkan kabel jala listrik kesumber daya,

5. Membuka atau putar kekanan tombol panik,

6. Mengendorkan roda beban berlawanan jarum jam (tidak sampai lepas) atau tanpa beban,

7. Mengatur tampilan forcemeter menjadi nol, dengan memutar potensio di sisi kanan panel,

8. Mereset countermeter dan menekan tombol reset di panel,

9. Menekan tombol Run-Stop untuk mengaktifkan motor speed control,

10. Menekan tombol start pada speed control, frekuensi ditingkatkan secara bertahap sampai putaran tertentu (dapat diperhatikan di tachometer),

11. Mengamati forcemeter dan coutermeter untuk keperluan data,

12. Mesin akan berhenti otomatis jika benda uji putus atau patah,

13. Melepaskan hubungan kabel jala listrik kesumber daya.

14. Mengeluarkan patahan benda uji dari ruang mesin uji fatik. 


\section{Diagram Alir Penelitian}

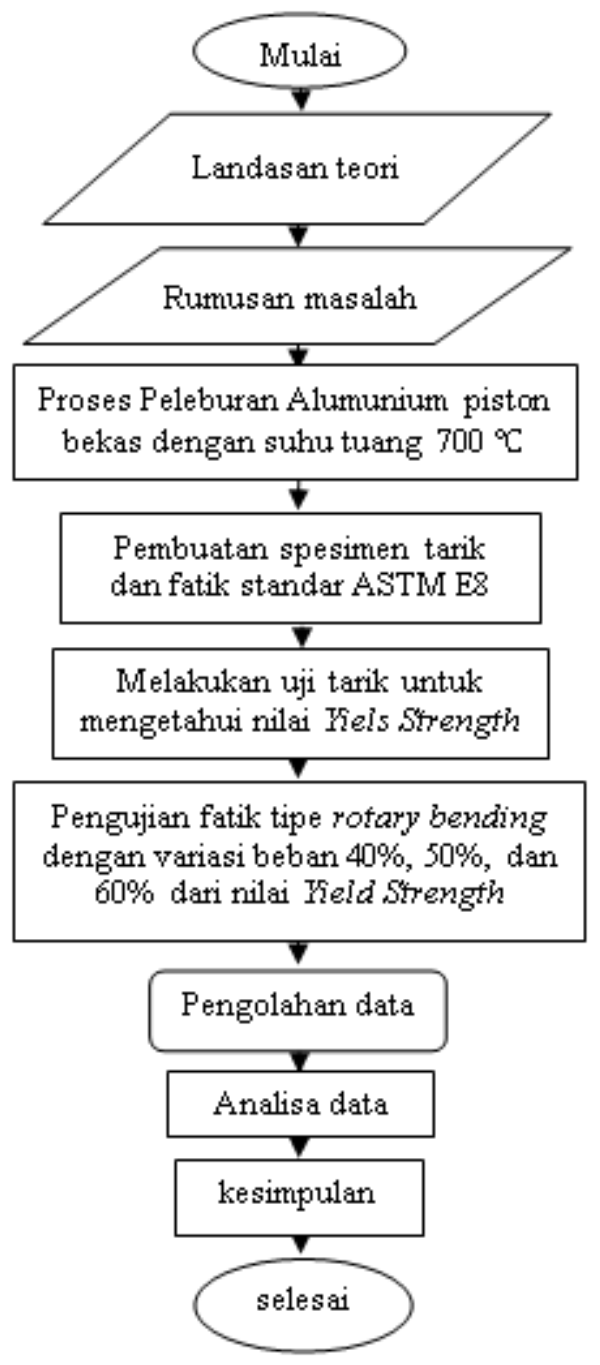

Gambar 6. Diagram alir penelitian

\section{HASIL DAN PEMBAHASAN}

Dari pengujian tarik didapatkan data seperti pada tabel 4.

Tabel 4. Hasil Pengujian Tarik

\begin{tabular}{|c|c|c|c|}
\hline $\begin{array}{c}\text { Spesime } \\
\mathrm{n}\end{array}$ & $\begin{array}{c}\text { Utimat } \\
\text { e Stress } \\
(\mathrm{MPa})\end{array}$ & $\begin{array}{c}\text { Yiels } \\
\text { Strengt } \\
h \\
(\mathrm{MPa})\end{array}$ & $\begin{array}{c}\text { Elasticit } \\
y \\
\text { Modulus } \\
(\mathrm{MPa})\end{array}$ \\
\hline 1 & $\begin{array}{c}124,71 \\
6\end{array}$ & 124,716 & 62.193 \\
\hline 2 & 124,92 & 124,92 & 63,29 \\
\hline 3 & $\begin{array}{c}124,50 \\
1\end{array}$ & 124,501 & 61,09 \\
\hline Rata-rata & $\begin{array}{c}124,71 \\
6\end{array}$ & 124,716 & 62.193 \\
\hline
\end{tabular}

Untuk menentukan beban yang digunakan dalam pengujian, dari data spesifikasi aluminium scrap hasil remelting piston bekas memiliki Yield Strength $125 \mathrm{MPa}$.

Data-data yang diketahui adalah sebagai berikut :

$$
\begin{aligned}
& \mathrm{L}=180 \mathrm{~mm} \\
& \mathrm{~d}=6 \mathrm{~mm} \\
& \sigma=125 \mathrm{Mpa}
\end{aligned}
$$

Perhitungan beban pada pengujian $40 \%$ dari Yield Strength

$$
\begin{gathered}
\sigma=\frac{w \cdot l / 2}{\pi / 32 . d^{3}} \mathrm{~kg} / \mathrm{cm}^{2} \\
125 \mathrm{MPa} \times 40 \%=\frac{\frac{w .180 \mathrm{~mm}}{2}}{\frac{\pi}{32 .(6 \mathrm{~mm})^{3}}} \mathrm{~kg} / \mathrm{cm}^{2} \\
\frac{w .180 \mathrm{~mm}}{2}=(125 \mathrm{MPa} \times 40 \%) \cdot\left\{\frac{\pi}{32} .(6 \mathrm{~mm})^{3}\right\} \\
\frac{w .180 \mathrm{~mm}}{2}=1059,75 \mathrm{~N} / \mathrm{mm} \\
w .180 \mathrm{~mm}=1059,75 \times 2 \mathrm{~N} / \mathrm{mm} \\
w=\frac{2119,5}{180} \mathrm{~N} \\
w=11,77 \mathrm{~N} \\
w=1,2 \mathrm{Kg}
\end{gathered}
$$

Perhitungan beban pada pengujian $50 \%$ dari Yield Strength

$$
\begin{aligned}
& \sigma=\frac{w \cdot l / 2}{\pi / 32 \cdot d^{3}} \mathrm{~kg} / \mathrm{cm}^{2} \\
& 125 \mathrm{MPa} \times 50 \%=\frac{\frac{w .180 \mathrm{~mm}}{2}}{\frac{\pi}{32 .(6 \mathrm{~mm})^{3}}} \mathrm{~kg} / \mathrm{cm}^{2} \\
& \frac{w .180 \mathrm{~mm}}{2}=(125 \mathrm{MPa} \times 50 \%) \cdot\left\{\frac{\pi}{32} \cdot(6 \mathrm{~mm})^{3}\right\} \\
& \frac{w .180 \mathrm{~mm}}{2}=1059,75 \mathrm{~N} / \mathrm{mm} \\
& w .180 \mathrm{~mm}=1325.35 \times 2 \mathrm{~N} / \mathrm{mm} \\
& w=\frac{2650,7}{180} N \\
& w=14,73 \mathrm{~N} \\
& w=1,5 \mathrm{Kg}
\end{aligned}
$$

Perhitungan beban pada pengujian $60 \%$ dari Yield Strength

$$
\sigma=\frac{w \cdot l / 2}{\pi / 32 \cdot d^{3}} \mathrm{~kg} / \mathrm{cm}^{2}
$$

$125 \mathrm{MPa} \times 60 \%=\frac{\frac{w .180 \mathrm{~mm}}{2}}{\frac{\pi}{32 .(6 \mathrm{~mm})^{3}}} \mathrm{~kg} / \mathrm{cm}^{2}$

$$
\begin{gathered}
\frac{w .180 \mathrm{~mm}}{2}=(125 \mathrm{MPa} \times 60 \%) \cdot\left\{\frac{\pi}{32} \cdot(6 \mathrm{~mm})^{3}\right\} \\
\frac{w .180 \mathrm{~mm}}{2}=1590,45 \mathrm{~N} / \mathrm{mm} \\
\begin{array}{c}
w .180 \mathrm{~mm}=1059,75 \times 2 \mathrm{~N} / \mathrm{mm} \\
w=\frac{3180,9}{180} \mathrm{~N}
\end{array}
\end{gathered}
$$




$$
\begin{aligned}
& w=17,67 N \\
& w=1,8 K g
\end{aligned}
$$

Setelah melakukan perhitungan didapat hasil pada tabel 5 .

Tabel 5. Beban pengujian fatik

\begin{tabular}{|c|c|c|c|c|}
\hline No & $\begin{array}{c}\text { Yield } \\
\text { Strength } \\
(\mathrm{MPa})\end{array}$ & $\begin{array}{c}\text { Variasi } \\
\text { Beban Uji } \\
\text { Fatik (\%) }\end{array}$ & $\begin{array}{c}\sigma \\
(\mathrm{MPa})\end{array}$ & $\begin{array}{c}\mathrm{W} \\
(\mathrm{kg})\end{array}$ \\
\hline 1 & 125 & 40 & 50 & 1,2 \\
\hline 2 & 125 & 50 & 62,5 & 1,5 \\
\hline 3 & 125 & 60 & 75 & 1,8 \\
\hline
\end{tabular}

Setelah dilakukan perhitungan untuk menentukan beban yang akan diuji pada aluminium scrap hasil remelting piston bekas dengan menggunakan mesin uji fatik rotary bending didapat hasil dengan pembebanan 40\%, 50\%, dan 60\% dari nilai Yield Strength, hasil pengujian bisa dilihat pada tabel 6 .

Tabel 6. Hasil pengujian 40\%, 50\%, dan $60 \%$ dari Yield Strength

\begin{tabular}{|c|c|c|c|c|c|}
\hline No & $\begin{array}{c}\sigma_{\gamma} \\
(\mathrm{MPa})\end{array}$ & $\begin{array}{c}\text { Beban } \\
(\mathrm{kg})\end{array}$ & $\begin{array}{c}\text { Kec. } \\
\text { Putar } \\
(\mathrm{rpm})\end{array}$ & $\begin{array}{c}\text { Siklus } \\
(\text { putaraan })\end{array}$ & $\begin{array}{c}\text { Waktu } \\
(\mathrm{h}: \mathrm{m}: \mathrm{s})\end{array}$ \\
\hline 1 & 50 & 1,2 & 1500 & 171026 & $01: 54: 01$ \\
\hline 2 & 62,5 & 1,5 & 1500 & 56794 & $00: 29: 51$ \\
\hline 3 & 75 & 1,8 & 1500 & 24384 & $00: 16: 15$ \\
\hline
\end{tabular}

Dari pengujian yang dilakukan didapat hasil pengujian pada tabel 6 di atas memiliki nilai yang berbeda dalam 3 pembebanan yaitu 40\%, 50\%, dan 60\%. Setiap pembebanan ada 3 (tiga) kali pengujian yang didapat sampai waktu spesimen mengalami kelelahan (patah). Perbedaan pembebanan mempengaruhi beban yang diberikan pada spesiman. Jadi dapat dilihat bahwa pemberian beban yang besar akan mengakibatkan spesiman mengalami kegagalan dalam waktu yang lebih cepat Begitu pula sebaliknya jika beban yang diberikan kecil maka waktu spesiman mengalami kegagalan atau kelelahan (patah) lebih lama.

Setelah mendapatkan hasil pengujian fatik yang dilakukan terhadap spesiman didapat data dalam bentuk kurva S-N yang terlihat pada gambar 7 .

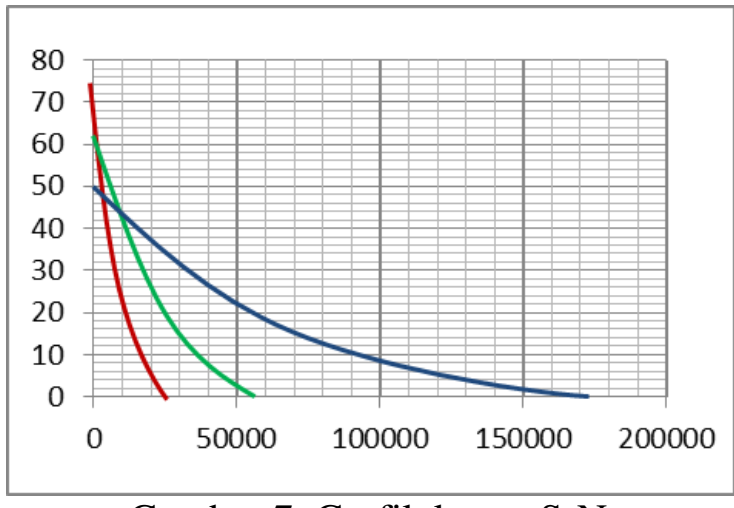

Gambar 7. Grafik kurva S-N

Dari kurva S-N pengujian aluminium scrap hasil remelting piston bekas di atas, dapat dilihat perbandingan antara siklus dengan tegangan. Pada grafik kurva S-N diatas menunjukkan bahwa garis warna merah mempunyai tegangan $75 \mathrm{MPa}$ dengan siklus 24384 putaran, garis warna hijau mempunyai tegangan lebih rendah yaitu sebesar $62,5 \mathrm{MPa}$ dan mempunyai siklus 56794 putaran, lebih besar nilai dari warna merah. Garis warna biru mempunyai tegangan paling rendah yakni $50 \mathrm{MPa}$ dengan siklus paling tinggi yakni 171026 putaran. Jadi semakin kecil tegangan yang diberikan pada spesimen semakin besar nilai siklus yang didapat, itupun sebaliknya semakin besar tegangan yang diberikan pada spesimen semakin kecil nilai siklus yang didapat.

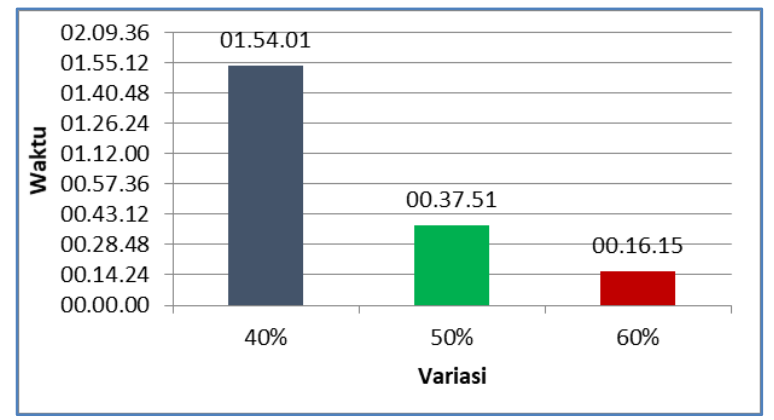

Gambar 7. Waktu yang diperoleh selama penelitian berlangsung.

\section{KESIMPULAN}

Dari hasil pengujian fatik pada pembebanan $40 \%$ dengan beban $1,2 \mathrm{~kg}$ mendapatkan siklus 141.026 pada waktu 
patah 01:34:01 detik, kemudian pembebanan $50 \%$ dengan beban $1,5 \mathrm{~kg}$ mendapatkan siklus 56.794 pada waktu patah 00:37:51 detik, dan pada pembebanan $60 \%$ dengan beban $1,8 \mathrm{~kg}$ mendapatkan siklus 24.384 pada waktu patah 00:16:15 detik. Jadi semakin besar tegangan yang di berikan semakin kecil siklus dan waktu yang dihasilkan, begitu pula sebaliknya semakin kecil tegangan yang diberikan semakin besar siklus dan waktu yang dihasilkan.

\section{REFERENSI}

[1]. Ihsan Emira Eldina, Gusdika Candra,

Nandi Firdaus, Setri Delfita

Sari, Ananda Putra. 2016.

Aluminium. Jurusan Kimia.

Universitas Negri Padang.

[2]. Pratowo Bambang. Novran Apriansyah. 2010. Analisa Kekuatan Fatik Baja Karbon Rendah SC10 Dengan Tipe Rotary Bending. Teknik Mesin. Fakultas Teknik. Universitas Bandar Lampung.

[3]. Rusnanto. 2013. Studi Kekuatan Impek Pada Pengecoran Paduan AL-SI (Piston Bekas)Dengan Penambahan Unsur Mg. Jurusan Teknik Mesin. Fakultas Teknik. Universitas pancasakti Tegal.

[4]. Ricardo Ery. 2013. Pengaruh Komposisi Paduan Al ADC 12 Hasil Daur Ulang Gram Terhadap Sifat Mekanik. Jurusan Teknik Mesin. Fakultas Teknik. Universitas Gunadarma. Jl. Akses Kelapa Dua, Ciamanggis.

[5]. Budiyanto. 2008. Pengaruh Temperatur Penuangan

Paduan AL-SI (seri 4032)

Terhadap Hasil Pengecoran.

Teknik Mesin. Fakultas

Teknologi Industri. Istitut

Teknologi Nasional Malang.
[6]. Tawaf Nanang. Wahyono Suprapto. Anindito Purnowidodo. 2014. Analisa Fatigue Faiture Suhu Rendah Struktur Batang Duralumin Dengan Mesin Siklus Bending. Jurusan Teknik Mesin. Fakultas Teknik. Universitas Brawijaya. Malang.

[7]. ASTM S. International. standard Test Methods for Tonsion Teating of Metallic Materials. 2010. 